Journal of Tropical Ecology

http://journals.cambridge.org/TRO

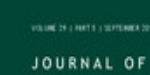

Additional services for Journal of Tropical Ecology:

Email alerts: Click here

Subscriptions: Click here

Commercial reprints: Click here

Terms of use : $\underline{\text { Click here }}$

\title{
Seed dispersal by the lek-forming white-bearded manakin (Manacus manacus, Pipridae) in the Brazilian Atlantic forest
}

César Cestari and Marco Aurélio Pizo

Journal of Tropical Ecology / Volume 29 / Issue 05 / September 2013, pp 381 - 389

DOI: 10.1017/S0266467413000412, Published online: 19 July 2013

Link to this article: http://journals.cambridge.org/abstract_S0266467413000412

How to cite this article:

César Cestari and Marco Aurélio Pizo (2013). Seed dispersal by the lek-forming white-bearded manakin (Manacus manacus, Pipridae) in the Brazilian Atlantic forest. Journal of Tropical Ecology, 29, pp 381-389 doi:10.1017/

S0266467413000412

Request Permissions : $\underline{\text { Click here }}$ 


\title{
Seed dispersal by the lek-forming white-bearded manakin (Manacus manacus, Pipridae) in the Brazilian Atlantic forest
}

\author{
César Cestari ${ }^{1}$ and Marco Aurélio Pizo
}

Departamento de Zoologia, Universidade Estadual Paulista 'Julio de Mesquita Filho' (Unesp), Avenida 24A, 1515, Bela Vista, Rio Claro, SP, CEP 13506-900, Brasil

(Received 28 February 2013; revised 9 June 2013; accepted 10 June 2013; first published online 19 July 2013)

\begin{abstract}
The movement patterns of males, females and juveniles of lekking species often differ due to differences in the commitment to lek activities, which may lead to differences in the spatial distribution and dispersal distances of seeds they eat. By sampling seeds in three lek and non-lek areas of the white-bearded manakin (Manacus manacus), we tested whether this lekking species increased the abundance and species richness of seeds in lek areas and, at a finer scale, in 21 displaying courts within lek areas. Combining data on seed defecation or regurgitation rates by free-ranging individuals, the number of seeds in droppings or regurgitations of mist-netted birds, and the distances travelled by birds equipped with radio-transmitters, we estimated the potential spatial distribution of seeds generated by six resident males and six females or juveniles during the morning peak of lek activity and when lek activity decreased in the afternoon. There was no difference in the species richness ( 46 and 44 morphospecies, respectively) and abundance of seeds ( $15.4 \pm$ 7.3 seeds and $14.0 \pm 1.1$ seeds, respectively) between lek and non-lek areas. Within leks both parameters increased in courts (45 spp., $17.6 \pm 14$ seeds) compared with non-court sites (22 spp., $1.9 \pm 1.8$ seeds), likely as a consequence of the longer time spent by resident males in perches in or near display courts. Distances moved by juveniles and females per 60 -min period $(183 \pm 272 \mathrm{~m})$ were greater than resident males $(42.6 \pm 22.0 \mathrm{~m})$ in the mornings, while the opposite happened in the afternoons $(55.2 \pm 40.7 \mathrm{~m}$ and $157 \pm 105 \mathrm{~m}$, respectively). We conclude that the spatial aggregation of seeds in lek areas of M. manacus occurs at the court level, and the spatial distribution of deposited seeds varies with manakin lekking status and the daily period of foraging.
\end{abstract}

Key Words: frugivory, movement ecology, Neotropic, radio-telemetry, seed aggregation

\section{INTRODUCTION}

How far seeds are moved from maternal plants and how they are distributed in space by dispersal agents are key topics for the understanding of the reproductive success of individual plants (Côrtes \& Uriarte 2013). As a general rule, the farther from its maternal plant a seed is deposited the higher its chance of escape from mortality (Jansen et al. 2008). Dispersal distance, however, is not the only factor influencing the survival probability of seeds; their spatial distribution also matters. For instance, seeds deposited in clumps may have little chance of surviving due to competitive interactions among neighbouring seeds (Schupp et al. 2002). The capacity to move seeds long distances and spread them apart from each other are thus components of seed-dispersal effectiveness (Schupp et al. 2010).

\footnotetext{
${ }^{1}$ Corresponding author. Email: cesar_cestari@yahoo.com.br
}

Lekking frugivorous animals present interesting opportunities to investigate intraspecific differences in seed-dispersal effectiveness because males, females and juveniles have different movement patterns resulting from different commitments to lek activities. While males remain stationary in lek areas where they hold display territories, females and juveniles generally move widely to visit different leks (Graves et al. 1983, Théry 1992). The long permanence of males in lek areas often result in the deposition of a great variety and density of seeds that ultimately may influence the structure and composition of the vegetation (Karubian et al. 2012, Krijger et al. 1997, Théry \& Larpin 1993).

In Manacus manakins (Passeriformes, Pipridae), males are most active in the lek during early morning and early afternoon. Outside of these periods, lek activity decreases and males spend a variable amount of time out of lek areas. Juvenile males and females may visit different leks in a day, but most of the time they stay out or in the vicinity of lek areas (Cestari \& Pizo 2012, Chapman 1935, Lill 1974a, 
Snow 1962). Therefore, a seed ingested by a male during or immediately prior to its sedentary period in the day is expected to be dispersed to smaller distances than if the same seed was ingested prior to a bird's period of more intense movement (Westcott et al. 2005).

We investigated the seed rain in lek areas of the white-bearded manakin (Manacus manacus), and the seed dispersal activity by resident males and females/juveniles in the Brazilian Atlantic forest. More specifically, we asked the following questions: are there differences in the abundance and species richness of seeds falling in lek and non-lek areas, and, at a finer-scale, in male courts (i.e. display areas) and non-court sites within lek areas? Is there any spatial structure in the composition of the seed rain deposited at male courts? Considering the movements of manakins, we asked: do resident males and females/juveniles differ in the potential seed distribution they provide during the daily period of peak activity in leks and when lek activity decreases? We hypothesized that a greater abundance and species richness of bird-dispersed seeds would reach lek areas than non-lek areas, and courts than non-court sites due to the constant presence and deposition of seeds by lekking males (Cestari 2010). We also expected that juveniles and females would generate a more extensive distribution of seeds than the more sedentary lekking males.

\section{METHODS}

\section{Study species}

Manacus manacus is a small (15-18 g) understorey frugivorous bird that mainly inhabits lowland Neotropical forests. It has a widespread geographical distribution in continuous and fragmented Amazonian and Atlantic forests (Sick 1997, Snow 2004). Contrasting with the conspicuous black-and-white plumage of adult males, females and juveniles of both sexes have a dull green body colour. During the main breeding period that frequently overlaps with the rainy season, resident males concentrate their activities in lek areas measuring 18$23 \mathrm{~m}$ long and 4-9 m wide. Within a lek, each male establishes an oval 0.15-0.9-m-diameter court on the ground, which is actively cleaned from litter and usually delimited by two or more saplings wherein males display to attract females. Courts may be separated by $0.9-82.0 \mathrm{~m}$ from each other (Darnton 1958, Lill 1974a, Sick 1967, Snow 1962). Females and juvenile males frequently visit different lek areas to mate and practice display manoeuvres, respectively. Home ranges of female and juvenile males are typically 5-10 times larger than those of resident males (Lill 1974b, Théry 1992). Males may spend between $82-90 \%$ of daylight hours at lek areas during the main breeding season, leaving only during brief intervals to forage at nearby fruiting plants (Cestari \& Pizo 2012, Snow 1962, Théry 1992). During the annual moult period, resident males are absent from their courts for 2-3 mo, but lek areas may be used by juvenile males and adult males without territories to display in the temporarily vacant courts (Cestari \& Pizo 2012, Lill 1974b, Snow 1962).

\section{Study sites}

The study was conducted at two sites that included six lek areas in continuous lowland restinga forests in the state of São Paulo, south-eastern Brazil. Restinga is a coastal ecosystem included in the Atlantic forest domain composed of a structurally simple vegetation of halophytic herbs and shrubs close to the sea, and more complex vegetation in lowland and lower montane forests as one moves into the continent (Sampaio et al. 2005). Typical plant families are Myrtaceae, Leguminosae, Rubiaceae, Melastomataceae, Lauraceae and Annonaceae (Mamede et al. 2004). Four leks (Leks 0-3) of white-bearded manakin were located in a protected reserve (Juréia Itatins Ecological Station - JIES $-24^{\circ} 18^{\prime} \mathrm{S}, 47^{\circ} 00^{\prime} \mathrm{W}$ ) while the other two leks (Leks 4-5) were located in a non-protected area (NPA - $24^{\circ} 10^{\prime} \mathrm{S}, 46^{\circ} 55^{\prime} \mathrm{W}$ ) separated by nearly $38 \mathrm{~km}$ from the reserve border. Distances between leks exceed $5 \mathrm{~km}$ except for Lek 1 and Lek 2 separated by $0.6 \mathrm{~km}$ at their closest borders. The regional climate is humid subtropical. Mean annual rainfall is $2278 \mathrm{~mm}$ with the rainy season occurring from October to April, and the dry season from May to September. Mean annual temperature is $21.4^{\circ} \mathrm{C}$, with maximum and minimum temperatures averaging $25.8^{\circ} \mathrm{C}$ and $19.0^{\circ} \mathrm{C}$, respectively (Tarifa 2004).

\section{Seed rain}

We used $0.36-\mathrm{m}^{2}$ seed traps suspended $0.25 \mathrm{~m}$ above the ground to assess the seed rain at three lek areas (Lek 0, Lek 2, Lek 3) and three non-lek areas (up to $2500 \mathrm{~m}^{2}$ each) arranged in a paired design. Paired lek and non-lek areas were located $\sim 0.8 \mathrm{~km}$ from each other and had similar vegetation physiognomies. Seven seed traps were randomly distributed at each lek and non-lek area. We collected and counted seeds monthly from July 2009 to June 2011. Seeds were identified to the lowest taxonomic level possible by comparison with a reference collection and consultation with the literature and specialists. Plant nomenclature follows Missouri Botanical Garden's electronic databases (www.tropicos.org).

Seeds in court and non-court sites within lek areas were collected from March 2010 to February 2011, directly from the soil surface because the use of seed traps in courts would disturb male displays. We alternated monthly seed samples in NPA and JIES (i.e. each site was sampled at each 2-mo intervals), totalling six samples for each area. 


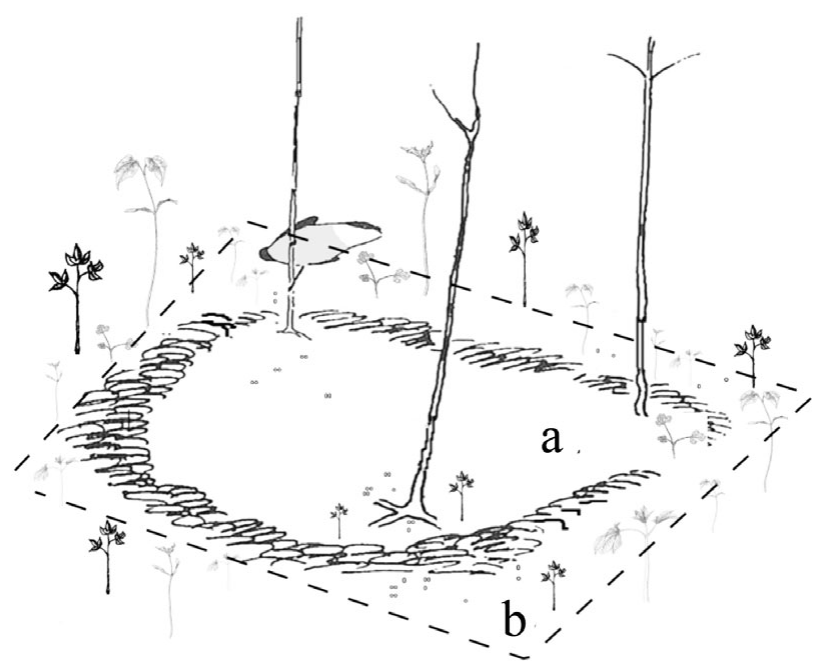

Figure 1. Schematic diagram of a court area of the white-bearded manakin (Manacus manacus) showing: the cleaned area of the court (a), and the border area of the court with numerous seedlings (b). Seeds are commonly found in a and $b$.

We defined a court site as a $0.22-\mathrm{m}^{2}$ area of bare soil where a male frequently performed its displays plus a $0.48-\mathrm{m}^{2}$ adjacent border area, generally covered with seedlings (Figure 1). Non-court sites with a similar shape and dimension to that of courts $\left(0.70 \mathrm{~m}^{2}\right)$ were delimited with a cord frame and set $5 \mathrm{~m}$ from courts in a random direction. A total of 21 courts and their paired non-court control areas were sampled, as follows: three courts in Lek 1, two courts in Lek 2, seven courts in Lek 3, eight courts in Lek 4 and one court in Lek 5 . Distances between courts were measured to analyse the spatial pattern of seed composition in courts within lek areas.

\section{Bird movements}

We used radio-telemetry to assess the distances moved by six resident males and six females/juveniles from Lek 0, Lek 2 and Lek 3. Females and juveniles were pooled in a single category because they are indistinguishable by size or plumage characteristics and we did not sex them. One resident male and one female/juvenile were monitored per month (September, October, December 2010 and May 2011), except in June 2011 when two resident males and two females/juveniles were monitored. Individuals captured on mist-nets placed in lek areas were kept for $30 \mathrm{~min}$ in a cage with foam-lined walls to avoid injury. We then attached a 0.3-g transmitter (Advanced Telemetry Systems, model A2414) to the back plumage using glue. Birds were radio-tracked for 60 consecutive minutes during the peak lekking period (morning: 06h15-09h00), and when the frequency of lek displays decreased or ceased (late afternoon: 15h15- 18h00). Previous observations of free-living radio-tagged individuals indicated that they foraged and flew without signs of annoyance after being released. Therefore, we used $1 \mathrm{~h}$ as a habituation interval prior to starting radiotracking. Werecorded 12 consecutive location fixes $(x$ and $y$ coordinates) per individual at 5-min intervals during one morning and one afternoon to obtain the straight-line distances between consecutive fixes. We remained $>10 \mathrm{~m}$ from the radio-tagged individuals to avoid interfering with their behaviour and used a high-sensitivity GPS receiver (Garmin eTrex Vista XCx, accuracy $<10 \mathrm{~m}$ ) to record fixes. When birds did not pluck transmitters off their backs, transmitters just fell off 5-15 d after being attached.

\section{Seed dispersal}

To quantify regurgitation or defecation rates we observed free-ranging adult males (187 samples) and females/juveniles (48 samples) in areas close to leks from July 2009 to June 2011. When a perched adult male or female/juvenile was detected, we started a stopwatch and followed it counting continuously the number of defecations and/or regurgitations before it flew away. We then calculated the mean rate of combined defecation/regurgitation per 5-min interval. We might have observed the same individuals more than once because not all individuals were colour-ringed. The mean number of seeds per defecation/regurgitation was obtained by counting the number of seeds in defecation and regurgitation samples from 12 monitored individuals (six resident males and six females/juveniles) and another 45 individuals (12 resident males and 33 females/juveniles) captured in leks from May 2009 to June 2011.

Seed distribution, here treated as the probability of seed deposition by radio-tracked birds at any distance from its origin, was estimated from the 60-min telemetry sample (12 fixes) by combining the straight-line distance moved by birds at each 5 -min period from a random initial point with the mean number of seeds defecated/regurgitated per 5-min interval. For example, if we obtained an average defecation/regurgitation rate of four seeds per $5 \mathrm{~min}$, an individual that moved $15 \mathrm{~m}$ (straight-line distance from an initial point) in the first $10 \mathrm{~min}$ of its route is expected to defecate/regurgitate eight seeds (four seeds each $5 \mathrm{~min}$ ) within $15 \mathrm{~m}$ of its original position. To apply this methodology, we assumed that foraging occurs randomly during the day (sensu Westcott et al. 2005).

\section{Data analyses}

To account for the temporal autocorrelation in monthly collections the number of seeds collected from traps in lek 


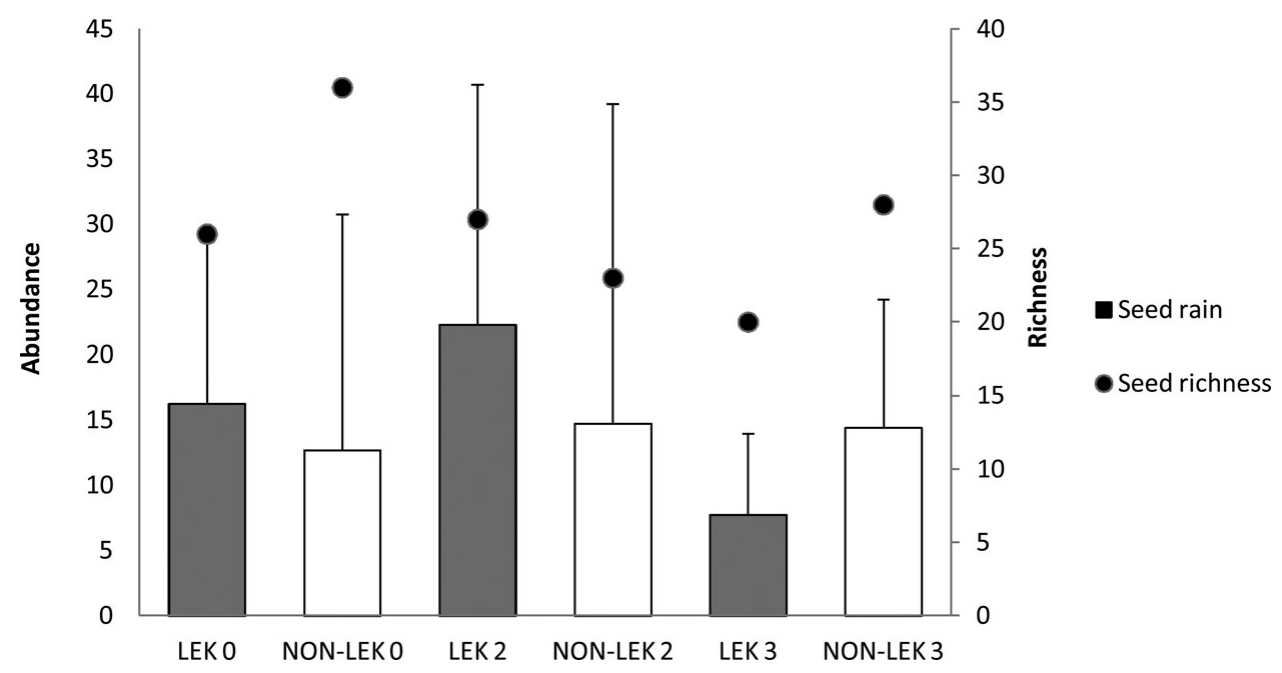

Figure 2. Mean abundance of seeds, and species richness of seeds in seed traps placed in three lek areas of the white-bearded manakin (Manacus manacus) and non-lek (control) paired areas over a 2-y period (July 2009-June 2011) in the Atlantic forest of south-eastern Brazil. Vertical lines represent SD. Seven seed traps of $0.36 \mathrm{~m}^{2}$ were used in each lek and control area.

and non-lek areas, and the number of seeds in courts and non-court sites within lek areas were compared with repeated-measures ANOVA. The monthly number of collected seeds was treated as a dependent variable. At a larger scale, lek and non-lek areas were used as factors, while in a smaller scale (within lek areas), courts and non-court sites were treated as factors.

Rarefaction analysis was used to compare the richness of seeds between lek and non-lek areas and between court and non-court sites using the Ecosim software 7.0. In this analysis, the number of seeds from control areas (either non-lek or non-court areas) was randomized for their respective lek or court areas through 1000 iterations to calculate the expected number of species. We reported the averaged rarified richness values for lek and court areas plus their variance $(\sigma)$, and $95 \%$ confidence intervals (CI).

Based on the abundances of seed morphospecies in the courts of leks with the greatest number of courts (Lek 3 and Lek 4) we calculated the similarity in seed composition using the Morisita's index $\left(C_{\lambda}\right)$, which varies from 0 (no similarity) to 1 (complete similarity).To test whether seed composition showed any spatial relationship with the distance among courts within a lek, we correlated the seed similarity and metric distances between courts using a Mantel test whose significance was determined by a permutation process with 1000 iterations. A positive or negative correlation between seed similarity and court distances indicates spatial structure in the composition of seeds deposited in lek areas. At a larger spatial scale, we also compared the seed composition between the group of courts from Lek 3 and Lek 4 using a non-parametric permutation procedure (ANOSIM) that considers a test statistic (R). $R$ values range from -1 to +1 , with dissimilarity between leks indicated by $R$ values greater than 0. Past 2.0 (Hammer et al. 2001) software was employed in the analyses of correlation and similarity.

Differences in the rate of defecation/regurgitation and in the number of seeds per defecation/regurgitation between resident males and females/juveniles were analysed using Mann-Whitney test. Differences in the straight-line distances moved between resident males and females/juveniles were compared in the morning and afternoon periods using repeated-measures ANOVA. Manakin status (resident males and females/juveniles), and daily periods (morning and afternoon) were treated as factors. Mann-Whitney test and ANOVAs were performed using Statistica software 10.0. Significance of test results was accepted at $\mathrm{P} \leq 0.05$.

\section{RESULTS}

The abundance of seeds in seed traps did not differ between lek and non-lek areas $\left(\mathrm{F}_{2,36}=2.44 ; \mathrm{P}=0.10\right.$; Figure 2). Species richness of seeds was similar between lek and nonlek areas ( 44 morphospecies; $\sigma=0.37 ; 95 \% \mathrm{CI}=42-44$ expected morphospecies; Appendix 1).

Courts had a greater abundance of seeds (17.6 \pm 14.0 seeds, $\mathrm{N}=21)$ than non-court sites $(1.9 \pm 1.8$ seeds, $\mathrm{N}=21 ; \mathrm{F}_{1,30}=23.8, \mathrm{P}<0.001$ ) indicating that seed deposition was concentrated in and around courts. Similarly, species richness of seeds was greater in courts than in non-court sites (45 morphospecies; $\sigma=4.85$; 95\% CI $=27-35$ expected morphospecies; Appendix 2).

Pairwise similarity in seed composition among courts within leks varied greatly (Lek 3: median $=0.15$; range $0.002-0.76, \mathrm{~N}=21$; Lek 4 : median $=0.46$, range $0.02-$ $0.75, \mathrm{~N}=28$ ), as did distances among courts (Lek 3: median $=48 \mathrm{~m}$, range 9-82 m; Lek 4: median $=14.2 \mathrm{~m}$, 
Table 1. Results of repeated-measures ANOVA on straight-line distances moved by individuals of the white-bearded manakin (Manacus manacus) in the Atlantic forest of south-eastern Brazil. Period refers to morning and afternoon periods, and manakin status to resident males and females/juveniles (taken together).

\begin{tabular}{llll}
\hline Effect & df & \multicolumn{1}{c}{ F } & P \\
\hline Period & 1 & 0.013 & 0.912 \\
Status & 1 & 0.314 & 0.583 \\
Period $\times$ Status & 1 & 4.99 & 0.04 \\
\hline
\end{tabular}

range 3-28.5 m). There was no correlation between similarity in seed composition and distances among courts in any of the lek areas (Lek 3: $\mathrm{R}=0.059, \mathrm{P}=0.34$; Lek $\left.4: R_{p}=-0.02, P=0.47\right)$ indicating no spatial structure in seed composition at the lek scale. ANOSIM analysis showed that Lek 3 and Lek 4 differed in the composition of seeds $\left(\mathrm{R}_{\mathrm{p}}=0.17 ; \mathrm{P}=0.04\right)$.

Resident males and females/juveniles did not differ in the combined defecation/regurgitation rate per 5-min interval (males: $4.4 \pm 10.2$ defecations, $\mathrm{N}$ = 187; females/juveniles: $3.6 \pm 7$ defecations, $\mathrm{N}=$ 48; $\mathrm{U}=4151, \mathrm{P}=0.37$ ) or in the number of seeds per defecation/regurgitation (males: $1.6 \pm 3.3$ seeds, $\mathrm{N}=18$; females/juveniles: $1.0 \pm 1.8$ seeds, $\mathrm{N}=$ 39; $\mathrm{U}=308 ; \mathrm{P}=0.45)$. Although the straight-line distances of resident males and females/juveniles did not differ, we detected a significant interaction involving lekking status and daily period (Table 1), indicating that males and females/juveniles potentially generated different seed distributions depending on daily periods. Females/juveniles moved longer straight-line distances than resident males in the mornings while the opposite happened in the afternoons (Table 1; Figure 3).

\section{DISCUSSION}

Contrary to our expectations, the seed abundance and species richness in the seed rain was similar between lek and non-lek areas, paralleling what Krijger et al. (1997) found for M. manacus in French Guiana, but in sharp contrast to other lekking bird species (Karubian et al. 2012, Théry \& Larpin 1993). The reasons for the differences between $M$. manacus and the few other lekking species studied so far regarding seed rain in lek areas remain elusive. We demonstrated, however, that the seed deposition promoted by M. manacus occurs at a scale smaller than the lek area, the scale of the displaying court in the vicinity of which resident males spend a great part of the day (Cestari 2010).

The deposition of seeds in courts constitutes an example of contagious seed dispersal in which some sites receive disproportionately more seeds than others (Schupp et al. 2002). This seed deposition pattern may result in seed limitation due to the disproportionate death of clumped seeds caused by competition and pathogens (Kwit et al. 2007). If this occurs then lek areas of M. manacus, more specifically their displaying courts, may represent ecological traps for seeds, especially for seeds coming from plants located in the vicinity of lek areas for which M. manacus has been shown to be the main seed remover (Cestari \& Pizo 2013). However, some of the seeds clumped in lek areas may survive, as recently demonstrated for lekking umbrellabird (Karubian et al. 2012) and antelope species (Jadeja et al. 2013). If this occurs, M. manacus may influence the structure (composition included) of plant communities in lek areas as showed for other species. For instance, Théry \& Larpin (1993) found a mosaic of plant species typical of different vegetation communities in a lek of the cock-of-the-rock (Rupicola rupicola) in French Guiana, showing that longterm seed dispersal by males promoted the succession from more open vegetation to forest physiognomy. Employing the genetic technique of maternally inherited tissue in seeds of the tropical palm Oenocarpus bataua, Karubian et al. (2010) revealed that the seed pool in a lek area of the long-wattled umbrellabird Cephalopterus penduliger have five times more source trees than control areas and reinforced the contribution of lekking birds for increasing the local genetic diversity of vegetation.

The high variability in seed composition of courts and the absence of spatial structure in seed composition among courts attest the contribution of M. manacus in depositing a variety of seeds in lek areas potentially increasing the local plant diversity. The difference in seed composition between lek areas nearly $38 \mathrm{~km}$ apart suggests that males of different leks forage on different plant species. Between-lek differences in plant phenology and composition, together with the opportunistic feeding habits of manakins that typically consume a wide variety of fruits (Krijger et al. 1997, Loiselle \& Blake 1990, Snow 1962, Worthington 1982) likely contributed to the between-lek variability in seed composition.

Straight-line distances moved by lekking males and females/juveniles of M. manacus differed between morning and afternoon periods. The seed dispersal distance promoted by females/juveniles in the mornings is expected to be four times larger than by resident males, whereas in the afternoon resident males are expected to disperse seeds for distances nearly three times greater than females/juveniles. In the mornings, males display in leks while females/juveniles visit leks sporadically (Cestari \& Pizo 2012, Snow 1962). During the afternoons, resident males are less committed with display activities thus allowing more time to move and forage while females/juveniles move less, likely because lek activities decrease and discourage their among-lek movements. These contrasting patterns of movements suggest a daily complementary role in the seed dispersal by resident males and 

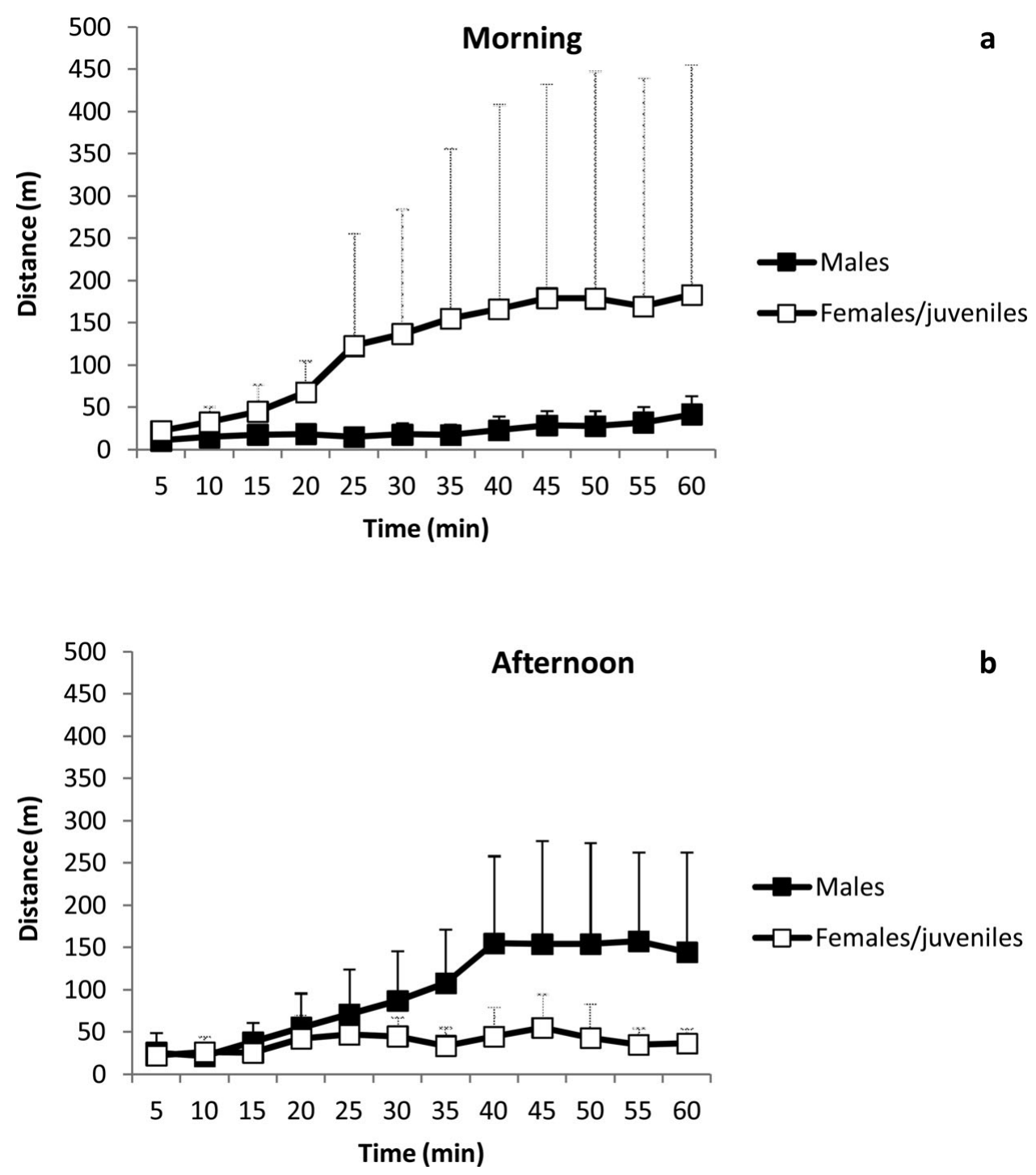

Figure 3. Straight-line distances moved by resident males $(\mathrm{N}=6)$ and females or juveniles $(\mathrm{N}=6)$ of the white-bearded manakin (Manacus manacus) from the points they were released $1 \mathrm{~h}$ after being equipped with radio-transmitters. Fixes were taken at 5-min intervals over $60 \mathrm{~min}$ during the mornings (06h15-09h00, a) and afternoons (15h15-18h00, b). Vertical lines represent SD.

females/juveniles: resident males disperse seeds closer to each other than females/juveniles in the mornings, while the opposite happened in the afternoons. Therefore, both the daily period of seed ingestion and lekking status matter for the seed dispersal distance provided by M. manacus.

Studies linking seed dispersal with the daily movements of birds and spatial use of lekking species are scarce. For the southern cassowary Casuarius casuarius, a 50-76-kg nonlekking bird from humid forests of Australia, Westcott et al. (2005) found dispersal distances three times larger in the mornings than in the afternoons due to the longer time that individuals spent foraging and moving during the early period of the day. In the case of M. manacus, differences in the commitment to lekking activities likely led to the daily differences in distances moved by resident males and females/juveniles.

In sum, we have shown that M. manacus potentially disperses a variety of seeds in Atlantic forest. Additionally, the spatial aggregation of seeds in lek areas of $M$. manacus occurred at the court level, and the spatial distribution of deposited seeds likely varies with manakin lekking status and the daily period of foraging. Future studies should address the consequences for plant recruitment of seed aggregation in courts, and if resident males and females/juveniles of M. manacus use different microhabitats, which may add to the daily differences in movement patterns to determine their effectiveness as seed dispersers. 


\section{ACKNOWLEDGEMENTS}

We are indebted to Ílson L. Prado and Cristina S. Gonçalves for help in the fieldwork. We also thank Rodrigo Tsuji for helping in the identification of plant species. CC and MAP receive research grants from the Brazilian Research Council (CNPq). Two anonymous reviewers made valuable suggestions in the manuscript. FAPESP (proc. No. 2009/17577-3 and 2012/20593-3) and CAPES (proc. No. 9729-11-9) provided financial support.

\section{LITERATURE CITED}

CESTARI, C. 2010. Anting behavior by the White-bearded Manakin (Manacus manacus, Pipridae): an example of functional interaction in a frugivorous lekking bird. Biota Neotropica 10:339-342.

CESTARI, C. \& PIZO, M. A. 2012. Lek phenology of the White-bearded Manakin (Manacus manacus, Pipridae) in a subtropical region. Journal of Natural History 46:2999-3009.

CESTARI, C. \& PIZO, M. A. 2013. Context-dependence in seed removal by lekking and non-lekking frugivorous birds in Brazilian of Atlantic forest. Wilson Journal of Ornithology. In press.

CHAPMAN, F. M. 1935.The courtship of Goulds' manakin (Manacus vitellinus) on Barro Colorado Island canal zone. Bulletin of the American Museum of Natural History 68:471-525.

CÔRTES, M. C. \& URIARTE, M. 2013. Integrating frugivory and animal movement: a review of the evidence and implications for scaling seed dispersal. Biological Reviews 88:255-272.

DARNTON, I. 1958. The display of the manakin Manacus manacus. Ibis 100:52-58.

GRAVES, G. R., ROBBINS, M. B. \& REMSEN, J. V. 1983. Age and sexual difference in spatial distribution and mobility in manakins (Pipridae): inferences from mist-netting. Journal of Field Ornithology 54:407412.

HAMMER, Ø., HARPER, D. A. T. \& RYAN, P. D. 2001. PAST: Paleontological statistics software package for education and data analysis. Palaeontologia Electronica 4:1-9.

JADEJA, S., PRASAD, S., QUADER, S. \& ISVARAN, K. 2013. Antelope mating strategies facilitate invasion of grasslands by a woody weed. Oikos (in press). doi: 10.1111/j.1600-0706.2013.00320.x

JANSEN, P. A., BONGERS, F. \& VAN DER MEER, P. J. 2008. Is farther seed dispersal better? Spatial patterns of offspring mortality in three rainforest tree species with different dispersal abilities. Ecography $31: 43-52$.

KARUBIAN, J., SORK, V. L., ROORDA, T., DURÃES, R. \& SMITH, T. B. 2010. Destination-based seed dispersal homogenizes genetic structure of a tropical palm. Molecular Ecology 19:1745-1753.

KARUBIAN, J., DURÃES, R., STOREY, J. L. \& SMITH, T. B. 2012. Mating behavior drives seed dispersal by the Long-wattled Umbrellabird Cephalopterus penduliger. Biotropica 44:689-698.

KRIJGER, C. L., OPDAM, M., THÉRY, M. \& BONGERS, F. 1997. Courtship behaviour of manakins and seed bank composition in a French Guianan rain forest. Journal of Tropical Ecology 13:631-636.

KWIT, C., LEVEY, D. J., TURNER, S. A., ClARK, C. J. \& POULSEN, J. R. 2007. Out of one shadow and into another: causes and consequences of spatially contagious seed dispersal by frugivores. Pp. 427-444 in Dennis, A. J., Green, R. J. \& Schupp, E. W. (eds.). Seed dispersal: theory and its application in a changing world. CABIPublishing, Wallingford.

LILL, A. 1974a. Sexual behavior of the lek-forming White-bearded Manakin (Manacus manacus trinidatis Hartert). Zeitschrift für Tierpsychologie 36:1-36.

LILL, A. 1974b. Social organization and space utilization in the lek-forming White-bearded Manakin (Manacus manacus trinitatis Hartert). Zeitschrift für Tierpsychologie 36:513-530.

LOISELLE, B. \& BLAKE, J. 1990. Diets of understory fruit-eating birds in Costa Rica: seasonality and resource abundance. Studies in Avian Biology 13:91-103.

MAMEDE, M. C. H., CORDEIRO, I, ROSSI, L., MELO, M. M. R. F. \& OLIVEIRA, R. J. 2004. Mata Atlântica. Pp. 115-132 in Marques, O. A. V. \& Duleba, W. (eds.). Estação Ecológica Juréia-Itatins. Ambiente físico, flora e fauna. Holos, Ribeirão Preto.

SAMPAIO, D., SOUZA, V. C., OLIVEIRA, A. A., PAULA-SOUZA, J. \& RODRIGUES, R. R. 2005. Árvores da restinga: guia de identificação. Neotrópica, São Paulo. 277 pp.

SICK, H. 1967. Courtship behavior in the manakins (Pipridae): a review. Living Bird 6:5-22.

SICK, H. 1997. Ornitologia Brasileira. Nova Fronteira, Rio de Janeiro. $862 \mathrm{pp}$.

SCHUPP, E. W., MILERON, T. \& RUSSO, S. E. 2002. Dissemination limitation and the origin and maintenance of species-rich tropical forests. Pp. 19-33 in Levey, D. J., Silva, W. R. \& Galetti, M. (eds.). Seed dispersal and frugivory: ecology, evolution and conservation. CABI Publishing, Wallingford.

SCHUPP, E., JORDANO, P. \& GÓMEZ, J. M. 2010. Seed dispersal effectiveness revisited: a conceptual review. New Phytologist 188:333353.

SNOW, D. 1962. A field study of the Black-and-white Manakin, Manacus manacus, in Trinidad. Zoologica 47:65-104.

SNOW, D. 2004. Family Pipridae (Manakins). Pp. 110-169 in del Hoyo, J., Elliot, A. \& Christie, D. A. (eds.). Handbook of the birds of the world: cotingas to pipits and wagtails. Lynx Editions, Barcelona.

TARIFA, J. R. 2004. Unidades climáticas dos maciços litorâneos da Juréia-Itatins. Pp. 42-50 in Marques, O. A. V. \& Duleba, W. (eds.). Estação Ecológica Juréia-Itatins. Ambiente físico, flora e fauna. Holos, Ribeirão Preto.

THÉRY, M. 1992. The evolution of leks through female choice differential clustering and space utilization in six sympatric manakins. Behavioral Ecology and Sociobiology 30:227-237.

THÉRY, M. \& LARPIN, D. 1993. Seed dispersal and vegetation dynamics at a Cock-of-the-rock's lek in the tropical forest of French Guiana. Journal of Tropical Ecology 9:109-116.

WESTCOTT, D. A., BENTRUPPERBAUMER, J., BRADFORD, M. G. \& MCKEOWN, A. 2005. Incorporating patterns of disperser behaviour into models of seed dispersal and its effects on estimated dispersal curves. Oecologia 146:57-67.

WORTHINGTON, A. 1982. Population size and breeding rhythms of two species of manakins in relation to food supply. Pp. 213-225 in Leigh, E. G., Rand, A. S. \& Windsor, D. M. (eds.). The ecology of a tropical forest: seasonal rhythms and long-term changes. Smithsonian Institution Press, Washington, DC. 
Appendix 1. Abundances of species and morphospecies of seeds collected in leks of Manacus manacus and non-lek areas from July 2009 to June 2011 in the Atlantic forest, south-eastern Brazil.

\begin{tabular}{|c|c|c|c|c|c|c|c|}
\hline \multirow[b]{2}{*}{ Plant family } & \multirow[b]{2}{*}{ Species/Morphospecies } & \multicolumn{3}{|c|}{ Lek areas } & \multicolumn{3}{|c|}{ Non-lek areas } \\
\hline & & $\overline{\mathrm{L} 1}$ & $\mathrm{~L} 2$ & $\mathrm{L3}$ & NL1 & NL2 & NL3 \\
\hline Anacardiaceae & Schinus sp. & 14 & 99 & 0 & 0 & 9 & 3 \\
\hline \multirow[t]{4}{*}{ Annonaceae } & Guatteria australis & 2 & 2 & 5 & 0 & 6 & 1 \\
\hline & G. nigrescens & 0 & 0 & 8 & 1 & 0 & 0 \\
\hline & Rollinia sericea & 0 & 0 & 0 & 0 & 23 & 0 \\
\hline & Xylopia sp. & 1 & 9 & 0 & 0 & 0 & 10 \\
\hline \multirow[t]{3}{*}{ Aquifoliaceae } & Ilex theezans & 8 & 2 & 4 & 14 & 0 & 0 \\
\hline & I. brevicusps & 9 & 0 & 0 & 50 & 0 & 0 \\
\hline & I. paraguariensis & 0 & 0 & 0 & 1 & 1 & 0 \\
\hline Araliaceae & Schefflera angustissima & 9 & 80 & 7 & 24 & 11 & 101 \\
\hline Arecaceae & Euterpe edulis & 0 & 2 & 0 & 0 & 1 & 0 \\
\hline Celastraceae & Maytenus robusta & 2 & 4 & 2 & 0 & 0 & 0 \\
\hline Chloranthaceae & Hedyosmum brasiliensis & 0 & 2 & 1 & 0 & 0 & 0 \\
\hline \multirow[t]{2}{*}{ Dilleniaceae } & Davilla rugosa & 4 & 4 & 3 & 1 & 0 & 2 \\
\hline & Doliocarpus sp. & 0 & 0 & 0 & 0 & 0 & 1 \\
\hline Ericaceae & Gaylussacia brasiliensis & 0 & 0 & 0 & 2 & 2 & 0 \\
\hline Euphorbiaceae & Pera glabrata & 25 & 23 & 7 & 2 & 0 & 15 \\
\hline \multirow[t]{3}{*}{ Lauraceae } & Ocotea pulchella & 25 & 66 & 5 & 12 & 4 & 11 \\
\hline & Endlicheria paniculata & 0 & 0 & 0 & 0 & 1 & 0 \\
\hline & Nectandra mollis & 0 & 2 & 0 & 0 & 0 & 0 \\
\hline \multirow[t]{3}{*}{ Melastomataceae } & Miconia ridigiuscula & 79 & 19 & 5 & 0 & 36 & 2 \\
\hline & M. cubatanensis & 19 & 70 & 18 & 24 & 4 & 47 \\
\hline & Ossaea sp. & 0 & 10 & 1 & 0 & 0 & 1 \\
\hline Moraceae & Ficus enormis & 0 & 27 & 0 & 0 & 3 & 0 \\
\hline \multirow[t]{2}{*}{ Myrsinaceae } & Rapanea parvifolia & 86 & 9 & 37 & 41 & 9 & 30 \\
\hline & R. ferruginea & 22 & 11 & 0 & 1 & 219 & 0 \\
\hline \multirow[t]{8}{*}{ Myrtaceae } & Blepharocalyx salicifolius & 5 & 1 & 0 & 0 & 0 & 2 \\
\hline & Calyptranthes concinna & 0 & 2 & 0 & 0 & 0 & 1 \\
\hline & Eugenia pluriflora & 37 & 11 & 4 & 31 & 0 & 1 \\
\hline & E. sulcata & 2 & 0 & 2 & 0 & 0 & 7 \\
\hline & E. umbelliflora & 8 & 0 & 2 & 2 & 0 & 15 \\
\hline & Myrcia sp. & 0 & 3 & 2 & 0 & 0 & 6 \\
\hline & Myrcia rostrata & 0 & 9 & 0 & 0 & 0 & 0 \\
\hline & Neomitranthes sp. & 0 & 3 & 1 & 0 & 2 & 3 \\
\hline Myrtaceae & Pimenta pseudocaryophyllus & 3 & 4 & 0 & 24 & 0 & 5 \\
\hline Pentaphyllaceae & Ternstroemia brasiliensis & 3 & 0 & 0 & 54 & 0 & 0 \\
\hline \multirow[t]{3}{*}{ Rubiaceae } & Psychotria carthagenensis & 0 & 6 & 1 & 0 & 1 & 0 \\
\hline & Psychotria sp. & 0 & 0 & 0 & 2 & 0 & 0 \\
\hline & Rudgea sp. & 2 & 0 & 5 & 1 & 0 & 5 \\
\hline Santalaceae & Phoradendron crassirostris & 0 & 16 & 5 & 1 & 7 & 6 \\
\hline Sapindaceae & Cupania oblongifolia & 0 & 9 & 1 & 1 & 4 & 26 \\
\hline Smilaceae & Smilax rufescens & 0 & 1 & 1 & 1 & 0 & 2 \\
\hline Symplocaceae & Paullinia sp. & 4 & 1 & 0 & 0 & 0 & 1 \\
\hline \multirow[t]{11}{*}{ Not identified } & Sp. 1 & 2 & 1 & 9 & 3 & 0 & 0 \\
\hline & Sp. 2 & 4 & 3 & 0 & 9 & 0 & 4 \\
\hline & Sp. 3 & 0 & 0 & 1 & 0 & 0 & 0 \\
\hline & Sp. 4 & 0 & 1 & 0 & 0 & 0 & 0 \\
\hline & Sp. 5 & 0 & 2 & 0 & 0 & 1 & 0 \\
\hline & Sp. 6 & 0 & 0 & 0 & 0 & 1 & 0 \\
\hline & Sp. 7 & 0 & 1 & 0 & 0 & 0 & 1 \\
\hline & Sp. 8 & 0 & 0 & 1 & 0 & 0 & 0 \\
\hline & Sp. 9 & 0 & 0 & 1 & 0 & 0 & 1 \\
\hline & Sp. 10 & 1 & 3 & 0 & 0 & 0 & 0 \\
\hline & Sp. 11 & 1 & 0 & 0 & 0 & 0 & 0 \\
\hline
\end{tabular}


Appendix 2. Abundances of species and morphospecies of seeds collected in courts of Manacus manacus and non-court sites in LEKs 1-5 from March 2010 to February 2011 in the Atlantic forest, south-eastern Brazil.

\begin{tabular}{|c|c|c|c|}
\hline Plant Family & Morphospecies & Court & Non-court \\
\hline Anacardiaceae & Schinus sp. & 16 & 8 \\
\hline \multirow[t]{2}{*}{ Annonaceae } & Guatteria nigrescens & 19 & 9 \\
\hline & Xylopia sp. & 7 & 0 \\
\hline \multirow[t]{2}{*}{ Aquifoliaceae } & Ilex theezans & 7 & 1 \\
\hline & I. paraguariensis & 7 & 0 \\
\hline \multirow[t]{2}{*}{ Araliaceae } & Schefflera morototoni & 136 & 13 \\
\hline & S. angustissima & 81 & 20 \\
\hline \multirow[t]{2}{*}{ Arecaceae } & Euterpe edulis & 1 & 1 \\
\hline & Geonoma schottiana & 16 & 0 \\
\hline Celastraceae & Maytenus robusta & 7 & 0 \\
\hline Chloranthaceae & Hedyosmum brasiliense & 5 & 0 \\
\hline Clusiaceae & Clusia criuva & 20 & 1 \\
\hline \multirow[t]{2}{*}{ Dilleniaceae } & Davilla rugosa & 23 & 1 \\
\hline & Doliocarpus sp. & 3 & 0 \\
\hline Euphorbiaceae & Pera glabrata & 24 & 0 \\
\hline Erythroxylaceae & Erythroxylum deciduum & 88 & 0 \\
\hline Lauraceae & Ocotea pulchella & 112 & 6 \\
\hline \multirow[t]{4}{*}{ Melastomataceae } & Miconia cubatanensis & 102 & 0 \\
\hline & M. hymenonervia & 14 & 0 \\
\hline & M. ridigiuscula & 36 & 1 \\
\hline & Ossaea sp. & 3 & 0 \\
\hline Meliaceae & Guarea macrophylla & 23 & 0 \\
\hline \multirow[t]{2}{*}{ Myrsinaceae } & Rapanea parvifolia & 492 & 68 \\
\hline & R. ferruginea & 121 & 3 \\
\hline \multirow[t]{9}{*}{ Myrtaceae } & Blepharocalyx salicifolius & 38 & 1 \\
\hline & Calyptranthes sp. & 0 & 1 \\
\hline & C. concinna & 42 & 2 \\
\hline & Eugenia pluriflora & 30 & 1 \\
\hline & E. umbelliflora & 126 & 14 \\
\hline & Myrcia bicarinata & 62 & 0 \\
\hline & Myrcia sp. & 0 & 1 \\
\hline & Pimenta pseudocaryophyllus & 25 & 1 \\
\hline & Siphoneugena guilfoyleiana & 1 & 0 \\
\hline Nyctaginaceae & Guapira opposita & 17 & 0 \\
\hline Pentaphyllaceae & Ternstroemia brasiliensis & 4 & 0 \\
\hline \multirow[t]{4}{*}{ Rubiaceae } & Chiococca alba & 12 & 0 \\
\hline & Psychotria carthagenensis & 11 & 0 \\
\hline & Psychotria sp. & 54 & 0 \\
\hline & Rudgea sp. & 4 & 0 \\
\hline Santalaceae & Phoradendron crassirostris & 0 & 15 \\
\hline Sapindaceae & Paullinia sp. & 39 & 3 \\
\hline Smilaceae & Smilax rufescens & 0 & 4 \\
\hline \multirow[t]{6}{*}{ Not identified } & Sp. 1 & 18 & 0 \\
\hline & Sp. 2 & 2 & 0 \\
\hline & Sp. 3 & 1 & 0 \\
\hline & Sp. 4 & 2 & 0 \\
\hline & Sp. 5 & 2 & 0 \\
\hline & Sp. 6 & 2 & 0 \\
\hline
\end{tabular}

